\title{
The Impact of Foliar Application of Calcium Fertilizers on the Quality of Highbush Blueberry Fruits Belonging to the 'Duke' Cultivar
}

\author{
Ireneusz OCHMIAN \\ West Pomeranian University of Technology in Szczecin, Laboratory of Orcharding at the Department of \\ Horticulture,Stowackiego 17,71-434Szczecin,Poland; ochir@o2.pl; ireneusz.ochmian@zut.edu.pl
}

\begin{abstract}
The studies were conducted in the period of 2010-2011, in the Laboratory of Orcharding at the West Pomeranian University of Technology in Szczecin, and related to the bushes of the highbush blueberry of the Duke cultivar. The authors examined the impact of foliar calcium fertlizers (Calcinit, Calcium chloride, Fruton Calcium Calcium, Folanx Ca29 Lebosol Calcium Forte Calcium Forte) on the fruit size and firmness, their chemical composition, content of macronutrients in the foliage and fruits, and their colour. It was found that the applied fertlizers have varied impact on the examined attributes. The bushes sprayed with the Lebosol Calcium Forte and Calcinit preparations had big fruits with a high content of $\mathrm{K}$ and $\mathrm{Mg}$, and dark foliage. The application of the Lebosol Calcium Forte fertilizer increased the content of polyphenols and vitamin $\mathrm{C}$ in the fruits. The smallest amounts of such compounds were determined in the fruits sprayed with the Calcinit fertilizer. The highest firmness and resistance to mechanical damage were achieved in the case of the fruits collected from the bushes sprayed with the foliar fertlizers containing calcium chloride, such as Fruton Calcium and Folanx Ca29. It was determined that the application of the calcium preparations resulted in the increase of the calcium content in the fruits and foliage. The highest amounts of this element were determined in the case of the plants sprayed with the Folanx Ca29 and Lebosol Calcium Forte preparations.
\end{abstract}

Keywords: calcium, chemical composition, color, firmness, Vaccinium corymbosum

\section{Introduction}

The cultivars of the highbush blueberry derive from the Vaccinium sp. plants, which grows in the wild in soils that are poor in nutrients. In effect, the fertilizer requirements of the blueberry, as compared to other fruit plants, are relatively low (Gough, 1994; Pliszka, 2002; Smolarz, 2003). However, high yielding, intensive irrigation and use of mulches make it necessary to complement and maintain the constant levels of macro- and micronutrients in plants and soil profiles (Pormale et al., 2009). One of the aims of the producer is to preserve the high post-harvest quality of fruit. An important indicator of fruit freshness and attractiveness is their firmness, especially after the storage period. The mechanical strength of the fruit peel and pulp depends, to a large extent, on the condition of their cell membranes, and in particular, on the chemical composition of pectins connecting plant cells to form tissues (Starck, 2007). The major role in this process is carried out by calcium, which, by forming a part of phospholipids, contributes to the stabilisation of cell membranes, thus affecting their permeability (Szweykowska, 2004; White and Broadley, 2003). The deficiency or transport disorder of calcium results in a number of physiological diseases, thus decreasing, among others, the storage and commercial value of the fruit (Shear, 1975). An increasing importance is placed on the role of calcium as a secondary infor- mation transmitter. In combination with calmodulin, this element participates in several basic metabolic processes (Snedden and Fromm, 2001; Zhang and Lu, 2003).

Plant roots absorb calcium from the soil solution in the form of $\mathrm{Ca}^{2+}$ ions (Clarkson, 1993; White, 2001); however, the high content of humus leads to the limitation on the quantity of free calcium ions, while organic acids form chelate complexes with $\mathrm{Ca}^{2+}$ ions (Starck, 2007). A low $\mathrm{pH}$ of the substrate affects the high concentrations of $\mathrm{Al}^{3+}$, $\mathrm{Fe}^{2+}$, and $\mathrm{Mn}^{2+}$ ions, inhibiting the up taking of calcium ions (Clarkson and Sanderson, 1971; Haynes, 1986). An alternative solution is, therefore, to supply calcium fertilizers by spraying the plants. The calcium supply to the foliage does not influence the concentration of this element in the fruits (Saure, 2005). For this reason, the best results are achieved when the solution of calcium preparation is applied directly to the fruit surface. The best assimilation of calcium is achieved by young fruit (Schlegel and Schönherr, 2002), since the permeability of cuticle is then the highest (Petit-Jimenez et al., 2009), and the properly functioning stomatal apparatus provides an easy passage for $\mathrm{Ca}^{2+}$.

The study describes the foliar application of calcium fertilizers with varied chemical composition to the bushes and the quality of highbush blueberry fruits, their size, colour, firmness and content of minerals and organic components. 
164

\section{Material and methods}

The studies were carried out in the years 2010-2011 in the Laboratory of Orcharding at the Department of Horticulture West Pomeranian University of Technology in Szczecin, on a production farm. 'Duke' blueberry bushes were planted in the spacing of $1.2 \times 2.0$ in the podzolic soil of the VI valuation class. The experiment followed a randomised sub-block design (3 blocks, 5 plants in each block). The content analysis of the soil minerals showed a very high level of magnesium, medium levels of phosphorus and calcium, and a low level of potassium. In spring, the nitrogen fertilization was applied at a dose of $45 \mathrm{~kg}$ $\mathrm{N} /$ ha.

Within the growing period, the bushes were sprayed 4 times with calcium solutions (every 10 days ranging from 1 June of the decade), starting from the fruit setting until the full wetting of the foliage. Liquid calcium fertilizers, designed for foliar fertilization of plants and fruit, were used, together with the Silwet Gold preparation enhancing the adhesion properties.

Calcinit $-0.5 \%$ solution:

$$
\begin{aligned}
& \mathrm{Ca}-19.0 \%, \mathrm{~N} 15.5 \%,\left(\mathrm{NO}_{3}-14.5 \%, \mathrm{NH}_{4}-1.0 \%\right) \\
& \text { (Yara Poland) }
\end{aligned}
$$

Ca $17.5 \%$ calculated as $\mathrm{CaO}$

(Spiess - Urania Chemicals GmbH)

Folanx $\mathrm{Ca} 29^{\circ} \mathrm{Ca} 29$ - $1 \%$ solution:

Calcium formate

(LANXESS Distribution GmbH)

Lebosol Calcium Forte Calcium Forte - $1 \%$ solution: Ca-13.5\%, Mn-1.5\%, Zn-0.5\%

(Lebosol Calcium Forte Dünger GmbH).

Immediately after the harvests - 3 times from the third decade of July - the unit weight, dimensions and firmness of the fruits were determined (plunger $25 \mathrm{~mm}$ ), as well as their resistance to mechanical damage (a 3-mm plunger) by using a non-destructive device connected to the FirmTech 2 computer. At any time, a set of measurements was performed on 100 fruits, The chemical composition of fruit was also determined: total acidity expressed as citric acid (PN-90/A-75101/04) was determined using a titration method, as well as the content of vitamin $\mathrm{C}$ and nitrates by means of test strips read by the electronic refractometer, RQfleks10 (Merck), and the content of total extract using the refractometric method.

The blueberries collected at each harvest were frozen and stored at the temperature of $-31^{\circ} \mathrm{C}$. For research purposes, the required amount of berries was defrosted. The content of polyphenols and macronutrients was determined in these fruits. The total content of phenols, expressed as gallic acid, was estimated in methanol extractions, using the Folin-Ciocalteu reagent (Singleton and
Rossi, 1965). For macroelemental analyses in plant material, one hundred leaves of plants were sampled each year at the beginning of August. The estimation of the content of minerals was carried out in accordance with the Polish Standard (PN). After mineralisation, the total nitrogen content was determined with the Kjeldahl method (Ostrowska et al., 1991). The content of $\mathrm{K}$ and $\mathrm{Ca}$ was measured with the atomic emission spectrometry, whereas the $\mathrm{Mg}$ content was determined by means of flame atomic absorption spectroscopy using the SAA Solaar instrument. The phosphorus content was determined with the Barton method at a wavelength of $470 \mathrm{~nm}$, whereas the sulphur content with the turbidimetric method at a wavelength of $490 \mathrm{~nm}$, employing the spectrophotometer Marcel s 330 PRO.

Prior to the first harvest of fruits, the index of leaf greenness was measured (after 5 leaves in 25 replicates for each fertilizer), using the Chlorophyll Meter SPAD-502 (Minolta) apparatus, and the foliage was taken for chemical analyses. In autumn, the mean foliage area was measured using the DIAS scanner connected to the computer.

Leaf (in which the green index is measured - 5 leaves in 25 replicates for each fertilizer) and fruit colour (per 100 fruits each time a set of fertilizer) were measured in a transmittance mode by means of a Konica Minolta CM-700d spectrophotometer in 1-cm-thick glass trays. Measurements were conducted in a CIE L*a*b* system $\left[\mathrm{L}^{*}\right.$ white (100) black $(0), a^{*}$ green $(-100)$ red $(+100), b^{*}$ blue $(-100)$ yellow $(+100)]$, through a $10^{\circ}$ observer type and D65 illuminant.

In order to determine the significance of differences, a one-factor analysis of variance was carried out, followed by the assessment of the significance of differences using the Tukey's test. To determine the relation between the applied fertlizers and fruit firmness, the results obtained were subjected to an agglomerative cluster analysis and classified into groups in a hierarchical order by means of the Ward's method. The statistical analyses were performed using the Statistica software.

\section{Results and discussion}

\section{Size of fruit}

Fruit size and firmness are of decisive importance for the harvest quality. The results showed a high variability of these parameters, resulting from the application of foliar calcium fertilizers (Tab. 1). The biggest fruit was collected from the bushes sprayed with the Lebosol Calcium Forte $(343 \mathrm{~g})$ and Calcinit $(331 \mathrm{~g})$ fertilizers, their diameter and height exceeding $20 \mathrm{~mm}$. The smallest fruits were obtained from the bushes sprayed with calcium chloride and the Fruton Calcium fertilizer containing calcium chloride. The weight of 100 fruits was, respectively, $247 \mathrm{~g}$ and 278 $\mathrm{g}$, which was less than the mass of the fruit control group $(291 \mathrm{~g})$. The results indicate that the fruits taken from all bushes are of big size, the average mass of the 'Duke' 
blueberry being 1.5-1.9 g (Burkhard and Lynch1, 2009; Ehlenfeldt and Prior, 2001). Stückrath et al. (2008) having applied the preparation based on calcium oxide, also obtained smaller-size fruits $(1.94 \mathrm{~g})$, as compared to the control group $(2.54 \mathrm{~g})$.

\section{Fruit firmness and diameter}

Fruit firmness is of decisive importance in assessing, among other things, the fruit resistance to mechanical damage. It is commonly assumed that such a phenomenon is less intensive in fruits well supplied with calcium (Fallahi et al., 1997; Sams et al., 1993). The studies have confirmed the above assumption, which shows that the majority of fertilizers (calcium chloride, Folanx Ca29 and Fruton Calcium) enhances the firmness of the fruit, as compared to the control group (Tab. 1), both along the vertical axis (fruit height) and horizontal axis (fruit diameter). In contrast, all applied fertilizers have increased the fruit resistance to puncture. In comparison with other fruits, Duke cultivars are not very firm. Regardless of the fertilizers used, they show less firmness (control 325; sprayed 339-411 G.mm $\left.{ }^{1}\right)$, compared to the fruits of Sierra (440) and Patriot cultivars $\left(512 \mathrm{G} \cdot \mathrm{mm}^{-1}\right)$ (Ochmian et al., 2007, 2009). It was also (Duan et al., 2011) determined that the fruits of this cultivar were less firm than those of the Eliot cultivar. The findings on the influence of calcium on fruit firmness are ambiguous. The fruits soaked in the calcium solution after the harvest were more resistant to crushing (Hanson et al., 1993). Likewise, the fruits of the O'Neal cultivar were firmer than the fruits collected from the control group of bushes, but the results for the Bluecrop (Angeletti et al., 2010) cultivar showed a different trend.

The cluster analysis of the relationships between the applied fertilizers and fruit firmness is assessed along the vertical axis (fruit height) and horizontal axis (fruit diameters), and the puncture force of the fruits (Fig. 1). The fertilizers were divided into four groups. The fertilizers, the impact of which was the most similar on the studied attributes, were classified into one group. The Calcinit and Lebosol Calcium Forte, Fruton Calcium and Folanx Ca29 fertilizers showed the most similar results with regard to the means. The fruits from the control groups and those sprayed with calcium chloride constituted two separate groups of means.

\section{The chemical composition of fruits}

The research results in that field failed to show any influence of the applied calcium preparations on the extract content of the highbush blueberry fruit, which was at the level of $13.2 \%$ (control), but no more than $13.7 \%$ (Folanx Ca29). This is the range, within which the extract from the fruits of the Duke cultivar (Duan et al., 2011) lies, and of other cultivars, it ranges from $10 \%$ to $14.6 \%$ (Prior et al., 1998; Skupień, 2006).

Typically, highbush blueberry fruits contain a small amount of organic acids. The application of calcium fertilizers resulted in the additional reduction of the organic acid content in the fruits while increasing the juice $\mathrm{pH}$, as compared to the control group (Tab 1.). The fruits taken from the control group of bushes showed the highest con-

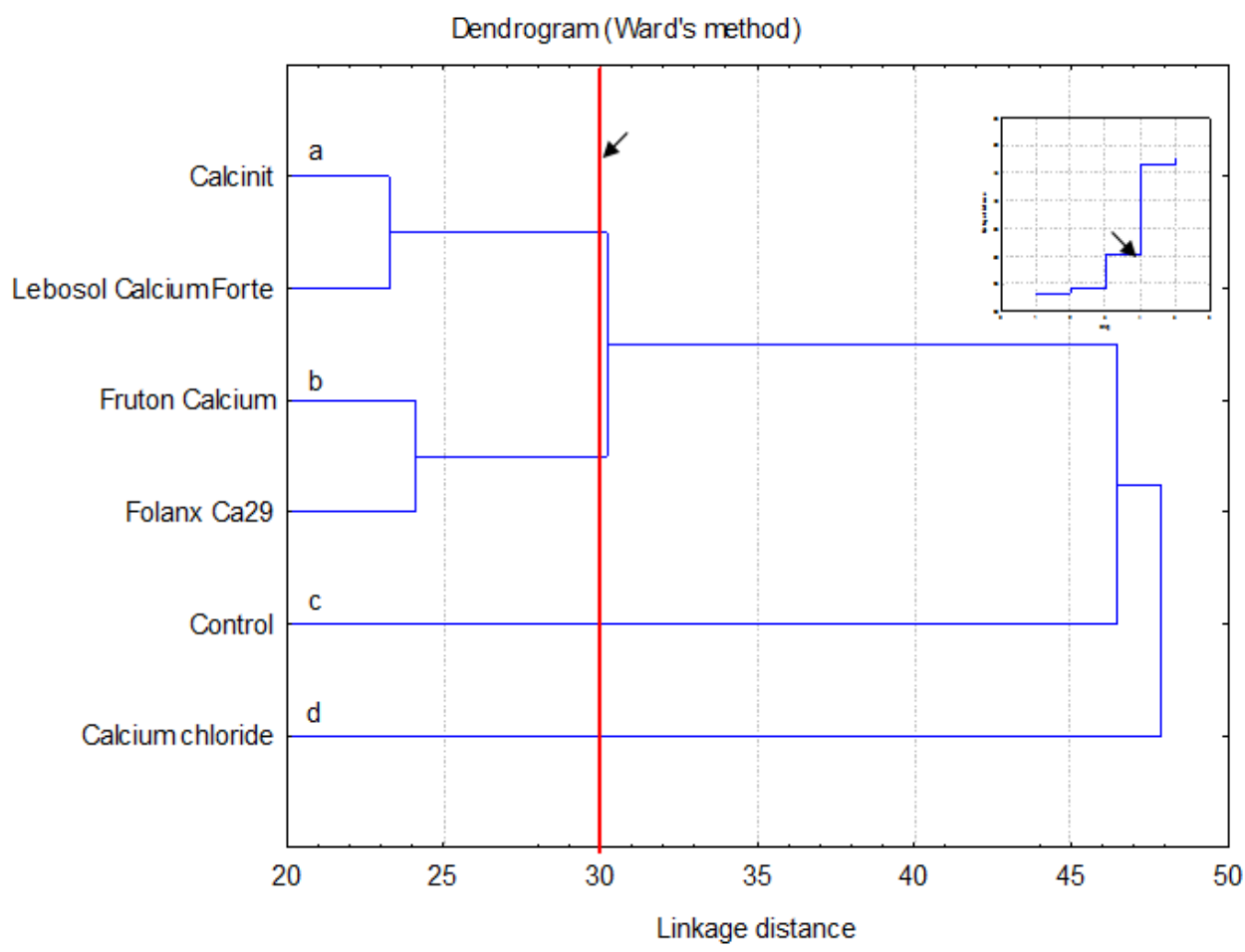

Fig. 1. Dendrogram of cluster analysis for fertilizers based on average for firmness.

The vertical line indicate the cut-off used to form the grups (a-d) 
166

tent of organic acid of $0.75 \mathrm{~g}$ and the lowest juice $\mathrm{pH}(\mathrm{pH}$ 3.62). The acidity of the fruits collected from the bushes sprayed with calcium fertilizers ranged from 0.52 to 0.75 $\mathrm{g}$, while the $\mathrm{pH}$ was 3.85 . These parameters are similar to those obtained by Duan et al. (2011).

The application of the majority of calcium fertilizers had an adverse effect on the content of polyphenols and vitamin $\mathrm{C}$ in the fruits. The content of these substances was higher in the control group of fruits (polyphenols 175 $\mathrm{mg}$, vit. C $139 \mathrm{mg}$ ). Only the use of the Lebosol Calcium Forte fertilizer, the chemical composition of which significantly differs from those of other fertilizers, resulted in the fruits of similar composition to that of the fruit control group. The level of polyphenols in the Duke cultivar (138 - $182 \mathrm{mg} \cdot 100 \mathrm{~g}^{-1}$ ) was much lower than the values determined by Moyer et al. (2002): $274 \mathrm{mg} \cdot 100 \mathrm{~g}^{-1}$, Prior et al. (1998): $305 \mathrm{mg} \cdot 100 \mathrm{~g}^{-1}$ or Bunea et al. (2011): $424 \mathrm{mg} \cdot 100$ $\mathrm{g}^{-1}$. The discoloured zone of the blueberry fruits is located around the fruit perimeter, and the research by other scientists shows that the content of polyphenolic compounds is generally higher in the fruit epidermis than in the fruit pulp (Chang et al., 2000). The fruits of the cultivars under study were much bigger than indicated in the references. The research by Ochmian (work in press) indicated that the total area of the small fruits was 20-25\% bigger than that of the big fruits, for $100 \mathrm{~g}$ of fruits. It may be the answer to the question why the fruits of the Duke cultivar having big fruits contain less polyphenolic compounds.

The assessment of the nitrogen content in the highbush blueberry fruits revealed a strong influence of calcium preparations, especially of the Calcinit and Fruton Calcium fertilizers. It was discovered that the fruits sprayed with these preparations had the highest nitrogen levels of, respectively, 31.3 and $36.7 \mathrm{mg} \cdot \mathrm{kg}^{-1}$. Nevertheless, these values are sufficient to allow the fruits to be consumed even by children. The control groups of fruits and those sprayed with the Folanx Ca29 fertilizer contained the smallest amount of nitrogens, i.e. a little above $20 \mathrm{mg}$. These values are similar to those obtained by other scientists, who determined the content of nitrogen in fruits at levels ranging from 15.5 to $34.7 \mathrm{mg} \mathrm{NO}_{3}$ (Ochmian et al., 2009, 2010; Ostrowska and Ściążko, 1996).

\section{Colour}

The aim of the experiment was also to examine the leaf greenness index, the colour and size of the foliage. The devices called chlorophyll meters facilitate the assessment of the total content of the chlorophyll, based on the highly correlated leaf greenness index (Gregorczyk and Raczyńska, 1997; Pacewicz and Gregorczyk, 2009). It was found that the impact of the applied fertilizers on the foliage colour, expressed both as SPAD index and $\mathrm{L}^{*} \mathrm{a}^{*} \mathrm{~b}^{*}$, is varied (Tab. 2). Definitely, the darkest foliage (parameter $\left.L^{*} 32.39\right)$, containing the highest amount of substances, that give a blue ( $\left.b^{*} 30.74\right)$ and green colour $\left(a^{*}-14.78\right.$ and SPAD 44.5), was determined in the case of the bushes fertilised by calcium nitrate. Such a result was most probably attributable to the chemical composition of the fertilizer, namely the high content of nitrogen, as evidenced by the analyses of the foliage collected from such bushes, which contained the highest amount of nitrogen (Tab. 3). A very similar effect was achieved by using the Lebosol Calcium Forte fertilizer. The sprayed plants also showed the biggest foliage. The application of the remaining fertilizers resulted in the foliage with parameters similar to those of the leaves collected from the control group of bushes. The only way to decrease the value of $b^{*}$ parameter was to apply calcium in the chloride form and the Folanx Ca29 fertilizer.

According to Krzewińska et al. (2010), the medium content of the chlorophyll in the foliage of the Bluecrop cultivar, (SPAD index), was determined at the level of 3948 units. The higher values were determined in the autumn season, compared to the measurements taken in spring.

Tab. 1. Some characteristics of the highbush blueberry 'Duke' fruits in dependence on fertilizing (mean for 2010-2011)

\begin{tabular}{ccccccc}
\hline & \multicolumn{5}{c}{ Applied fertilizers } \\
\cline { 2 - 6 } Variable & Calcinit & $\begin{array}{c}\text { Calcium } \\
\text { chloride }\end{array}$ & $\begin{array}{c}\text { Fruton } \\
\text { Calcium }\end{array}$ & $\begin{array}{c}\text { Folanx } \\
\text { Ca29 }\end{array}$ & $\begin{array}{c}\text { Lebosol } \\
\text { Calcium Forte }\end{array}$ & Control \\
\hline 100 fruits mass $(\mathrm{g})$ & $331 \mathrm{~cd}^{*}$ & $247 \mathrm{a}$ & $278 \mathrm{ab}$ & $305 \mathrm{bc}$ & $343 \mathrm{~d}$ & $291 \mathrm{~b}$ \\
\hline Fruit height $(\mathrm{mm})$ & $20.2 \mathrm{c}$ & $14.8 \mathrm{a}$ & $17.1 \mathrm{~b}$ & $18.0 \mathrm{~b}$ & $20.1 \mathrm{c}$ & $17.6 \mathrm{~b}$ \\
\hline Fruit diameter $(\mathrm{mm})$ & $23.0 \mathrm{bc}$ & $16.1 \mathrm{a}$ & $20.6 \mathrm{~b}$ & $21.3 \mathrm{bc}$ & $23.6 \mathrm{c}$ & $20.4 \mathrm{~b}$ \\
\hline Fruit firmness measured on height axis $(\mathrm{G} \mathrm{mm})$ & $357 \mathrm{ab}$ & $411 \mathrm{~b}$ & $369 \mathrm{~b}$ & $373 \mathrm{~b}$ & $339 \mathrm{a}$ & $325 \mathrm{a}$ \\
\hline Fruit firmness measured on diameter axis $(\mathrm{G} \mathrm{mm})$ & $173 \mathrm{a}$ & $223 \mathrm{~b}$ & $204 \mathrm{~b}$ & $182 \mathrm{ab}$ & $166 \mathrm{a}$ & $147 \mathrm{a}$ \\
\hline Puncture the fruit diameter axis $(\mathrm{G} \mathrm{mm})$ & $125 \mathrm{ab}$ & $153 \mathrm{~b}$ & $140 \mathrm{~b}$ & $149 \mathrm{~b}$ & $138 \mathrm{~b}$ & $98 \mathrm{a}$ \\
\hline Soluble solids $(\%)$ & $13.5 \mathrm{a}$ & $13.3 \mathrm{a}$ & $13.4 \mathrm{a}$ & $13.7 \mathrm{a}$ & $13.5 \mathrm{a}$ & $13.2 \mathrm{a}$ \\
\hline Titratable acidity $\left(\mathrm{g} \cdot 100 \mathrm{~mL}^{-1}\right)$ & $0.52 \mathrm{a}$ & $0.61 \mathrm{ab}$ & $0.65 \mathrm{ab}$ & $0.55 \mathrm{a}$ & $0.59 \mathrm{a}$ & $0.75 \mathrm{~b}$ \\
\hline Juice $\mathrm{pH}$ & $3.81 \mathrm{~b}$ & $3.76 \mathrm{ab}$ & $3.71 \mathrm{ab}$ & $3.83 \mathrm{~b}$ & $3.85 \mathrm{~b}$ & $3.62 \mathrm{a}$ \\
\hline Total polyphenol $\left(\mathrm{mg}^{\prime} \cdot 1000 \mathrm{~mL}^{-1}\right)$ & $138 \mathrm{a}$ & $154 \mathrm{~b}$ & $165 \mathrm{bc}$ & $168 \mathrm{bc}$ & $182 \mathrm{~d}$ & $175 \mathrm{~cd}$ \\
\hline Vitamin C $\left(\mathrm{mg} \cdot 1000 \mathrm{~mL}^{-1}\right)$ & $98 \mathrm{a}$ & $117 \mathrm{ab}$ & $121 \mathrm{bc}$ & $104 \mathrm{a}$ & $139 \mathrm{c}$ & $133 \mathrm{c}$ \\
$\mathrm{NO}_{3}\left(\mathrm{mg} \cdot 1000 \mathrm{~mL}^{-1}\right)$ & $31.3 \mathrm{bc}$ & $26.7 \mathrm{ab}$ & $36.7 \mathrm{c}$ & $22.4 \mathrm{a}$ & $27.3 \mathrm{ab}$ & $20.1 \mathrm{a}$ \\
\hline
\end{tabular}

*Explanation: Different letters within columns indicate significant differences by Tukey's HSD (Honestly Significant Difference) test at $p<0.05$ 


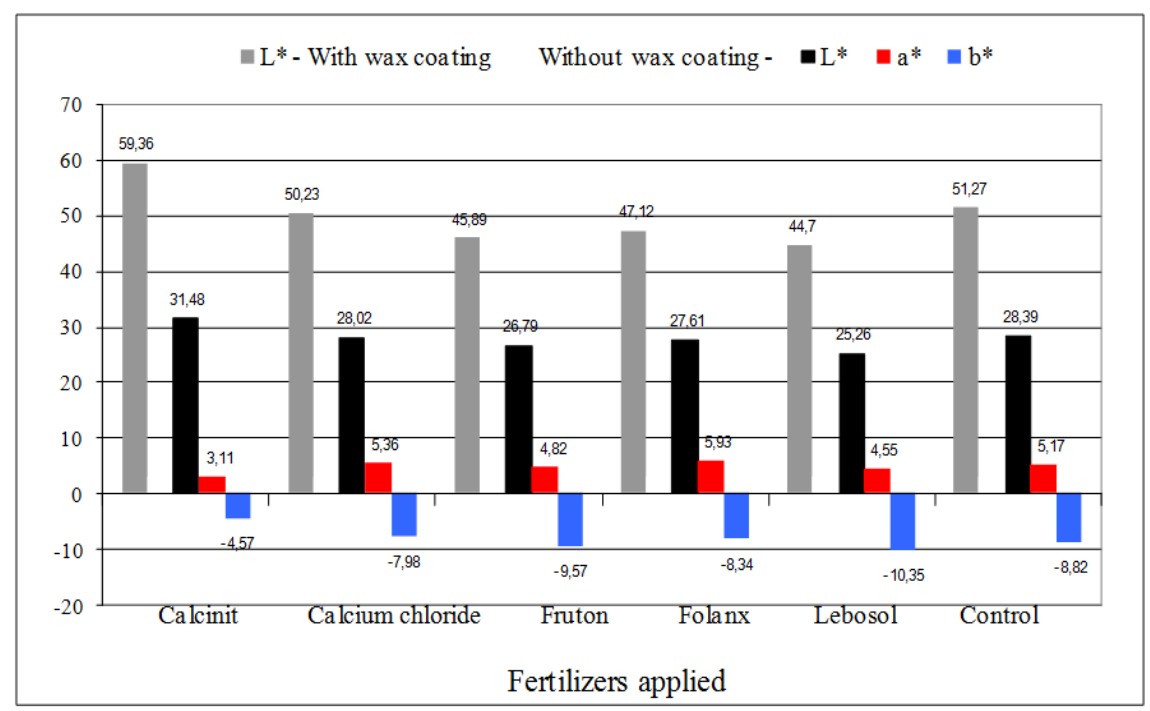

Fig. 2. The color of highbush blueberry 'Duke' depending on the applied calcium fertilizers

The estimation of the fruit colour showed that the fruits sprayed with the Calcinit fertilizer were the brightest, which is true for fruits both with and without a wax coating ( $L^{*}$ parameter - Fig. 2$)$. The application of the remaining fertilizers resulted in darker fruits than those from the control group. The darkest were fruits collected from bushes sprayed with the Lebosol Calcium Forte fertilizer. Such fruits also had the highest content of fruit pigments, giving a blue colour $\left(\mathrm{b}^{*}\right.$ parameter). The fruits sprayed with the Calcinit showed the lowest values of the $b^{*}$ and $a^{*}$ parameters, which determine the content of the pigments giving a red colour. The fruits of the highbush blueberry showed the values of the $a^{*}$ and $b^{*}$ parameters, which were similar to those of chokeberry fruits; however, they were brighter: blueberry fruits without a coating have $\mathrm{L}^{*}$ from 25.26 to 31.48 ), and chokeberry fruits have $L^{*}$ from 16.14 to 21.59 (Ochmian et al. 2012).

\section{Minerals in the foliage}

The foliage was collected for analysis in August, since according to Pliszka (2002), the earlier date of leaf collection is not recommended due to the relatively high dynamics of changes in the content of minerals. The higher content of calcium, both in the fruits and foliage of the
'Duke' blueberry, was determined as a result of the application of foliar calcium fertilizers (Tab. 3), though these differences were not always significant. The biggest increase of the calcium content, compared to the control group, was estimated as a result of the application of the Lebosol Calcium Forte and Folanx Ca29 preparations. Angeletti et al. (2010) claims that the application of foliar calcium fertilization resulted in a $10 \%$ increase of calcium in the fruits, compared to the control group. Stückrath $e t$ al. (2008) found that the concentration increase of this preparation contributed to the increase of the calcium content in fruits. By applying the preparation based on calcium oxide to the plants, they achieved a level of calcium content in the fruits of $0.0102 \%$. The results of their own study revealed that the calcium content in the fruits was at least three times higher, ranging from $0.034 \%$ (control) to 0.061\% (Lebosol Calcium Forte).

The application of the Calcinit fertilizers resulted in the biggest increase of $\mathrm{N}(2.47 \%), \mathrm{K}$ and $\mathrm{Mg}$ content, both in the foliage and fruits. The application of the Lebosol Calcium Forte fertilizer also resulted in the increase of $\mathrm{K}$ and $\mathrm{Mg}$ content in the fruits. The high content of nitrogen in the foliage and fruits is undoubtedly caused by the chemical composition of the fertilizer, which contains $15.5 \% \mathrm{~N}$.

Tab. 2. Characteristics of leaves of the highbush blueberry 'Duke' in dependence on the applied calcium fertilizers

\begin{tabular}{|c|c|c|c|c|c|c|c|}
\hline \multirow{2}{*}{\multicolumn{2}{|c|}{ Variable }} & \multicolumn{6}{|c|}{ Applied fertilizers } \\
\hline & & Calcinit & $\begin{array}{l}\text { Calcium } \\
\text { chloride }\end{array}$ & $\begin{array}{l}\text { Fruton } \\
\text { Calcium }\end{array}$ & Folanx Ca29 & $\begin{array}{c}\text { Lebosol } \\
\text { Calcium } \\
\text { Forte }\end{array}$ & Control \\
\hline Green i & & $44.5 b^{*}$ & $35.7 \mathrm{a}$ & $36.9 \mathrm{a}$ & $39.4 \mathrm{a}$ & $42.8 \mathrm{~b}$ & $38.4 \mathrm{a}$ \\
\hline \multirow{3}{*}{ Leaf color } & $\mathrm{L}^{*}$ & 32.39 & 45.08 & 39.77 & 40.13 & 36.42 & 42.42 \\
\hline & $a^{*}$ & -14.78 & -7.18 & -9.16 & -10.38 & -14.06 & -11.95 \\
\hline & $b^{*}$ & 30.74 & 15.73 & 14.08 & 16.56 & 28.31 & 26.31 \\
\hline \multicolumn{2}{|c|}{ Leaf area $\left(\mathrm{cm}^{2}\right)$} & $17.8 \mathrm{~b}$ & $15.9 \mathrm{a}$ & $16.1 \mathrm{a}$ & $16.5 \mathrm{ab}$ & $17.9 \mathrm{~b}$ & $17.1 \mathrm{ab}$ \\
\hline
\end{tabular}

*Explanation: Different letters within columns indicate significant differences by Tukey's HSD (Honestly Significant Difference) test at $p<0.05$ 
Tab. 3. The content of macroelements in fruits and leaves of highbush blueberry 'Duke' depending on the applied calcium fertilizers

\begin{tabular}{|c|c|c|c|c|c|c|c|c|}
\hline \multirow{2}{*}{\multicolumn{2}{|c|}{ Nutrient }} & & \multicolumn{6}{|c|}{ Applied fertilizers } \\
\hline & & & Calcinit & Calcium chloride & Fruton Calcium & Folanx Ca29 & $\begin{array}{c}\text { Lebosol } \\
\text { Calcium Forte }\end{array}$ & Control \\
\hline \multirow{5}{*}{ Fruits } & \multirow{10}{*}{$\begin{array}{l}{[\% \text { dry }} \\
\text { matter }]\end{array}$} & $\mathrm{Ca}$ & $0.045 \mathrm{ab}^{*}$ & $0.052 \mathrm{ab}$ & $0.047 \mathrm{ab}$ & $0.056 \mathrm{~b}$ & $0.061 \mathrm{~b}$ & $0.034 \mathrm{a}$ \\
\hline & & $\mathrm{N}$ & $1.14 \mathrm{c}$ & $0.63 \mathrm{ab}$ & $0.54 \mathrm{a}$ & $0.81 \mathrm{~b}$ & $0.69 a$ & $0.57 \mathrm{a}$ \\
\hline & & $\mathrm{P}$ & $0.075 \mathrm{ab}$ & $0.092 \mathrm{bc}$ & $0.055 \mathrm{a}$ & $0.121 \mathrm{~d}$ & $0.084 \mathrm{~b}$ & $0.110 \mathrm{~cd}$ \\
\hline & & $\mathrm{K}$ & $0.61 \mathrm{c}$ & $0.27 \mathrm{a}$ & $0.39 \mathrm{ab}$ & $0.46 \mathrm{ab}$ & $0.63 c$ & $0.55 b c$ \\
\hline & & $\mathrm{Mg}$ & $0.052 \mathrm{~b}$ & $0.027 \mathrm{a}$ & $0.033 \mathrm{a}$ & $0.039 \mathrm{ab}$ & $0.048 \mathrm{~b}$ & $0.044 \mathrm{ab}$ \\
\hline \multirow{5}{*}{ Leaves } & & $\mathrm{Ca}$ & $0.48 \mathrm{ab}$ & $0.77 \mathrm{c}$ & $0.86 \mathrm{c}$ & $0.63 \mathrm{bc}$ & $0.75 \mathrm{c}$ & $0.37 \mathrm{a}$ \\
\hline & & $\mathrm{N}$ & $2.47 \mathrm{c}$ & $1.54 \mathrm{ab}$ & $1.34 \mathrm{a}$ & $1.85 \mathrm{~b}$ & $1.93 \mathrm{~b}$ & $1.71 \mathrm{ab}$ \\
\hline & & $\mathrm{P}$ & $0.29 a$ & $0.22 \mathrm{a}$ & $0.25 \mathrm{a}$ & $0.17 \mathrm{a}$ & $0.31 \mathrm{a}$ & $0.22 \mathrm{a}$ \\
\hline & & $\mathrm{K}$ & $0.41 \mathrm{c}$ & $0.35 \mathrm{abc}$ & $0.26 \mathrm{a}$ & $0.29 \mathrm{ab}$ & $0.37 \mathrm{bc}$ & $0.33 a b c$ \\
\hline & & $\mathrm{Mg}$ & $0.28 \mathrm{c}$ & $0.17 \mathrm{ab}$ & $0.12 \mathrm{a}$ & $0.19 \mathrm{ab}$ & $0.22 b c$ & $0.16 \mathrm{a}$ \\
\hline
\end{tabular}

* Explanation: Different letters within columns indicate significant differences by Tukey's HSD (Honestly Significant Difference) test at $p<0.05$

The chemical analysis of the foliage indicated that the content of macronutrients was at the optimum level, and only the $\mathrm{N}$ content in the foliage sprayed with the Calcinit was too high, whereas the $\mathrm{K}$ content in the foliage collected from the plants sprayed with the Fruton Calcium and Folanx Ca29 fertilizers, and from the control group of plants, was too low. A similar level of the macronutrient content in the foliage was shown by Krzewińska et al. (2010), with the exception of $\mathrm{Ca}$ content, which was found to be much lower (0.21-0.32\%), as shown in the authors' own experiment (control 0.37; fertilised plants 0.48-0.86\%). It shows that all plants sprayed with calcium accumulated the highest amounts of this element.

\section{Conclusions}

The biggest fruits in terms of mass and size were collected from the bushes sprayed with Lebosol Calcium Forte and Calcinit fertilizers; however, these fertilizers did not improve the firmness of the fruits. The highest firmness and resistance to mechanical damage was achieved in case of the fruits collected from the bushes sprayed with the foliar fertilizers containing calcium chloride, such as Fruton Calcium and Folanx Ca29. The fruits collected from the bushes sprayed with the Lebosol Calcium Forte preparation had the highest content of polyphenols and vitamin C. The highest content of calcium in the fruits was found in the case of the plants sprayed with the Lebosol Calcium Forte and Folanx Ca29 preparations, who also picked up the $\mathrm{P}$ contents. Likewise, the high levels of $\mathrm{K}$ and $\mathrm{Mg}$ were found in the fruits that were sprayed with the Calcinit and Lebosol Calcium Forte fertilizers, and N - both in the foliage and fruits - when the Calcinit fertilizer was used. It was showed that the fertilizers had a similar impact on the colour and SPAD. The 'Duke' foliage, sprayed Calcinit and Lebosol Calcium Forte preparations, showed the highest Green Index, the darkest colour $\left(\mathrm{L}^{*}\right)$ and the highest content of compounds that give a green $\left(\mathrm{a}^{*}\right)$ and blue $\left(b^{*}\right)$ colour. The 'Duke' fruits, sprayed with calcium fertil- izers, had a brighter fruit peel $\left(\mathrm{L}^{*}\right)$, both with and without a wax coating, and contained less compounds that give a blue colour $\left(b^{*}\right)$, compared to the control group.

\section{Acknowledgements}

This work was supported by the Polish Ministry of Science and Higher Education under grant No. N N310 205337.

\section{References}

Angeletti P, Castagnasso H, Miceli E, Terminiello L, Concellon A, Chaves A, Vincente AR (2010). Effect of preharvest calcium applications on postharvest quality, softening and cell wall degradation of two blueberry (Vacciunium corymbosum) varieties. Post Biol Tech 58:98-103.

Bunea A, Rugină D, Pintea A, Sconța Z, Bunea C, Socaciu C (2011).Comparative Polyphenolic Content and Antioxidant Activities of Some Wild and Cultivated Blueberries from Romania. Not Bot Horti Agrobo 39(2):70-76.

Burkhard N, Lynch D (2009). Organic Mulch Impact on Vegetation Dynamics and Productivity of Highbush Blueberry Under Organic Production. HortSci 44(3):688696.

Chang S, Tan Ch, Frankel E, Barrett D (2000). Low-Density Lipoprotein Antioxidant Activity of Phenolic Compounds and Polyphenol Oxidase Activity in Selected Clingstone Peach Cultivars. J Agric Food Chem 48:147-151.

Clarkson DT (1993). Roots and the delivery of solutes to the xylem. Philos Trans R Soc London Ser B 341:5-17.

Clarkson DT, Sanderson J (1971). Inhibition of the uptake and long-distance transport of calcium by aluminium and other polyvalent cations. J Exp Bot 22:837-851.

Duan J, Wu R, Strik BC, Zhao Y (2011). Effect of edible coatings on the quality of fresh blueberries ('Duke' and Elliott) under commercial storage conditions. Postharv Biol Techn 59(1):71-79. 
Ehlenfeldt MK, Prior RL (2001). Oxygen Radical Absorbance Capacity (ORAC) and phenolic and anthocyanin concentrations in fruit and leaf tissues of highbush blueberry. J Agric Food Chem 49:2222-2227.

Fallahi E, Conway WS, Hickey KD, Sams CE (1997). The role of calcium and nitrogen in postharvest quality and disease resistance of apples. HortSci 32:831-835.

Gough R (1994). The highbush blueberry and its management. Food Products Press, N.Y.

Gregorczyk A, Raczyńska A (1997). Badania koleracji między metodą Arnona a pomiarami zawartości chlorofilu za pomocą chlorofilometru. Zesz Nauk AR Szczecin 181:119123.

Hanson E, Beggs J, Beaudry R (1993). Applying Calcium Chloride Postharvest to Improve Highbush Blueberry Firmness. HortSci 28(10):1033-1034.

Haynes RJ (1986). Laboratory study of soil acidification and leaching of nutrients from a soil amended with various surface-incorporated acidifying agents. Nutrient Cycling in Agroecosystems 2:165-174.

Krzewińska D, Smolarz K, Tryngiel-Gać A, Chlebowska D (2010). Wpływ sposobu przygotowania gleby na wzrost i owocowanie borówki wysokiej (Vaccinium corymbosum L.) odmiany Bluecrop. Zesz Nauk Inst Sad Kwiac 18:71-81.

Moyer RA, Hummer KE, Finn CE, Frei B, Wrolstad RE (2002). Anthocyanins, phenolic, and antioxidant capacity in diverse small fruits: Vaccinium, Rubus, and Ribes. J Agric Food Chem 50:519-525.

Ochmian I, Grajkowski J, Ostrowska K, Mikiciuk G (2007). Wzrost, plonowanie oraz jędrność owoców dwóch odmian borówki wysokiej (Vaccinium corymbosum L.) uprawianej w trzech typach podłoży organicznych. Zesz Nauk Inst Sadow Kwiac 15:47-54.

Ochmian I, Grajkowski J, Skupień K (2009). Influence of substrate on yield and chemical composition of highbush blueberry fruit cv. 'Sierra'. J Fruit Ornam Plant Res 17(1):89100 .

Ochmian I, Grajkowski J, Smolik M (2012). Comparison of Some Morphological Features, Quality and Chemical Content of Four Cultivars of Chokeberry Fruits (Aronia melanocarpa). Not Bot Horti Agrobo 40(1):253-260.

Ochmian I, Grajkowski J, Skupień K (2010). Effect of substrate type on the field performance and chemical composition of highbush blueberry cv. 'Patriot'. Agri Food Sci 19(1):69-80.

Ostrowska A, Gawliński S, Szczubiałka Z (1991). Metody analizy i oceny właściwości gleb i roślin. Wyd. Instytutu Ochrony Środowiska, Warszawa.

Ostrowska K, Sciążko D (1996). Zawartość składników bioorganicznych i mineralnych w owocach trzech odmian borówki wysokiej. Mat Konf II Ogólnopol Sym 40-lecia Wydz Ogrod AR w Poznaniu AR Poznań 17-19 września:225-229.

Pacewicz K, Gregorczyk A (2009). Porównanie ocen zawartości chlorofilu chlorofilometrami SPAD-502 i N-Tester. Folia
169

Pomer Univ Techno Stein Agric, Aliment, Pisc, Zootech, 269(9):46-49.

Petit-Jimenez D, Gonzalez-Leon A, Gonzalez-Aguilar G, SoteloMundo R, Baez-Sanudo R (2009). Permeability of cuticular membrane during the ontogeny of Mangifera indica L. Acta Hort 820:213-220.

Pliszka K (2002). Borówka wysoka. PWRiL, Warszawa.

Pormale J, Osvalde A, Nollendorfs V (2009). Comparison study of cultivated highbush and wild blueberry nutrient status in producing plantings and woodlands. Latvian J Agron 12:8087.

Prior RL, Cao G, Martin A, Sofic E, McEwen J, O’Brien C, Lischner N, Ehlenfeldt M, Kalt W, Krewer G, Mainland CM (1998). Antioxidant capacity as influenced by total phenolic and anthocyanin content, maturity, and variety of Vaccinium species. J Agric Food Chem 46:2686-2693.

Sams C, Conway W, Abbott J, Lewis R, Ben-Shalom N (1993). Firmness and decay of apples following postharvest pressure infiltration of calcium and heat treatment. J Amer Soc Hort Sci 118(5):623-627.

Saure MC (2005). Calcium translocation to fleshy fruit: its mechanism and endogenous control. SciHort 105:65-89.

Schlegel TK, Schönherr J (2002). Stage of development affects penetration of calcium chloride into apple fruits. J Plant Nutr Soil Sci 165:738-745.

Singleton VL, Rossi JA (1965). Colorimetry of total phenolics with phosphomolybdicphosphotungstic acid reagents. Am J Enol Vitic 16:144-158.

Shear CB (1975). Calcium-related disorders of fruits and vegetables. Hort Sci 10:361-365.

Skupień K (2006). Evaluation of chemical composition of fresh and frozen blueberry fruit (Vaccinium corymbosum L.). Acta Sci Pol Hortorum Cultus 5(1):19-25.

Smolarz K (2003). Uprawa borówki i żurawiny. Hortpress Sp.

Snedden WA, Fromm H (2001). Calmodulin as a versatile calcium signal transducer in plants. New Phytol 151:35-66.

Starck Z (2007). Gospodarka mineralna roślin. Fizjologia roślin. Red. Kopcewicz J., Lewak S. PWN Warszawa 228-271 p.

Stückrath R, Quevedo R, de la Fuente L, Hernandez A, Sepulveda V (2008). Effect of calcium foliar application on the characteristics of blueberry fruit during storage. J Plant Nutr 31:849-866.

Szweykowska A (2004). Fizjologia roślin. Wydawnictwo Naukowe UAM Poznań.

White PJ (2001). The pathways of calcium movement to the xylem. J Exp Bot 358:891-899.

White PJ, Broadley MR (2003). Calcium in plants. Ann of Bot 92:487-511.

Zhang L, Lu YT (2003). Calmodulin-binding protein kinases in plants. Trends Plant Sci 8:123-127. 